\title{
ANALISIS KARAKTERISTIK DAN TINGKAT PELAYANAN FASILITAS PEJALAN KAKI DI KAWASAN TERMINAL KENDARAAN UMUM KOTA DEPOK
}

\author{
(Analysis of The Charateristics And Level Of Service of Pedestrian Facility \\ in the Depok City Public Vehicle Terminal Area)
}

\author{
Fajar Tri Utomo ${ }^{1}$, A.R Indra Tjahjani ${ }^{1}$ \\ ${ }^{1}$ Program Studi Teknik Sipil Universitas Pancasila \\ E-mail: fajartriutom01993@gmail.com
}

\begin{abstract}
ABSTRAK
Wilayah studi penelitian ini dilakukan di salah satu kawasan Terminal Kendaraan Umum yang berada di kota Depok (JI. Margonda). Kawasan Terminal Kendaraan Umum yang berada di kota Depok tersebut selain menjadi pusat kawasan tempat pemberhentian sementara kendaraan umum untuk menaikan dan menurunkan penumpang, di kawasan tersebut juga terdapat pusat perbelanjaan yang mengakibatkan jalur pedestrian selalu ramai oleh pejalan kaki. Oleh sebab itu dilakukan penelitian yang bermaksud untuk menambah pengetahuan dan pemahaman mengenai kenyamanan suatu infrastruktur jalur pejalan kaki, serta bertujuan untuk mengetahui nilai variabel karakteristik pejalan kaki, hubungan variabel kecepatan dengan kepadatan, dan tingkat pelayanan fasilitas pejalan kaki tersebut. Dengan demikian dapat diketahui fungsi pengembangan dari fasilitas pejalan kaki tersebut. Dan metode yang digunakan dalam penelitian adalah menggunakan teknik manual, merujuk pada Peraturan Menteri Pekerjaan Umum Nomor : 03/PRT/M/2014. Data yang didapatkan dari hasil observasi adalah : jumlah pejalan kaki, waktu tempuh pejalan kaki, dan pengamatan visual di lapangan. Data diolah menjadi variabel karakteristik pejalan kaki seperti : arus, kecepatan, kepadatan, dan ruang. Untuk mendapatkan hubungan antara variabel kecepatan dan variabel kepadatan sesuai metode Greenberg, serta bentuk nilai dari kapasitas dan tingkat pelayanan fasilitas pejalan kaki di Kawasan Terminal Kendaraan Umum Kota Depok. Dan hasil peningkatan fasilitas pejalan kaki dapat dipertahankan di Kawasan Terminal Kendaraan Umum Kota Depok. Sesuai pedoman yang merujuk pada Peraturan Menteri Pekerjaan Umum Nomor : 03/PRT/M/2014.
\end{abstract}

Kata Kunci : fasilitas pejalan kaki, tingkat pelayanan, hubungan kecepatan-kepadatan, pengembangan fasilitas pejalan kaki, kawasan terminal.

\section{ABSTRACT}

The study area was conducted in one of the Public Vehicle Terminals located in Depok (Margonda). The area of Public Vehicle Terminal located in Depok city is not only the center of the area where the temporary stops of public transportation to raise and lower the passengers, there is also a shopping center which causes pedestrian lane always crowded by pedestrians. Therefore, the research aimed to increase the knowledge and understanding about the comfort of a pedestrian path infrastructure, as well as to know the variable values of pedestrian characteristics, the relation of speed variables with the density, and the level of service of the pedestrian facility. Thus can be known the development function of the pedestrian facility. And the method used in the research refers to Regulation of Minister of Public Work No. 03/PRT/M/2014. The data obtained from the observation are: the number of pedestrians, pedestrian travel time, and visual observation in the field. Data is processed into pedestrian characteristic variables such as: current, speed, density, and space. To obtain the relationship between speed variables and density variables according to Greenberg method, as well as the value form of capacity and service level of pedestrian facilities in Depok City Public Vehicle Terminal Area. And the improvement of pedestrian facilities can be maintained in the Depok City Public Vehicle Terminal Area. In accordance with the guidelines referring to the Regulation of the Minister of Public Works No. 03/PRT/M/2014.

Keywords : pedestrian facilities, service level, speed-density relationship, pedestrian facility development, terminal area. 


\section{PENDAHULUAN}

Jalur pejalan kaki merupakan salah satu wadah atau ruang yang digunakan para pejalan kaki untuk melakukan aktivitas dan untuk memberikan pelayanan kepada pejalan kaki sehingga dapat meningkatkan kelancaran, keamanan, dan kenyamanan bagi pejalan kaki. Jalur pejalan kaki merupakan bagian dari jalan yang berfungsi sebagai ruang sirkulasi bagi pejalan kaki yang terpisah bagi sirkulasi kendaraan. Dengan berjalan kaki, para pejalan kaki dapat mencapai semua sudut kota yang tidak dapat tersentuh dengan kendaraan bermotor. Pedestrian dalam hal ini memiliki arti pergerakan atau perpindahan orang atau manusia dari satu tempat ke tempat lain dengan menggunakan moda jalan kaki.

Pejalan kaki merupakan istilah dalam transportasi yang digunakan untuk menjelaskan orang yang berjalan di lintasan pejalan kaki baik dipinggir jalan, trotoar, lintasan khusus bagi pedestrian ataupun menyeberang jalan. Pada dasarnya kinerja lalu lintas pejalan kaki diekspresikan dengan cara yang mirip dengan ekspresi kinerja lalu lintas kendaraan yaitu dengan arus, kecepatan, dan kepadatan yang saling berhubungan.

Menurut Wolfang, S.H. et al (1986) pola pola aliran pejalan kaki memperhatikan beberapa kesamaan terhadap karakteristik lalu lintas kendaraan. Kecepatan, tingkat aliran dan kepadatan yang saling berhubungan. Bila tingkat aliran bertambah, kecepatan berkurang. Melewati tingkat aliran maksimum (kapasitas), kepadatan terus bertambah (kapasitas), kepadatan terus bertambah kearah kepadatan menumpuk. Sementara aliran dan kecepatan drop kearah nol. Karakteristik pejalan kaki sangat dipengaruhi oleh manusia. Faktor keinginan merupakan faktor yang utama dalam menentukan pola arus pedestrian, apakah ia ingin berjalan santai atau tergesa-gesa, apakah sendirian atau bersamasama dan sebagainya. Dengan adanya keanekaragaman ini, maka akan dicoba mengelompokkan karakteristik arus pejalan kaki berdasarkan kondisi dan keadaan tempat dimana arus tersebut diteliti dan berdasarkan pada maksud serta tujuan pejalan kaki tersebut melakukan aktivitasnya.

Wilayah studi penelitian ini dilakukan di salah satu kawasan Terminal Kendaraan Umum yang berada di kota Depok (Jl. Margonda). Kawasan Terminal Kendaraan Umum yang berada di kota Depok tersebut selain menjadi pusat kawasan tempat pemberhentian sementara kendaraan umum untuk meningkatkan kelancaran, keamanan, dan kenyamanan bagi pejalan kaki. Jalur pejalan kaki merupakan bagian dari jalan yang berfungsi sebagai ruang sirkulasi bagi pejalan kaki yang terpisah bagi sirkulasi kendaraan. Dengan berjalan kaki, para pejalan kaki dapat mencapai semua sudut kota menaikan dan menurunkan penumpang, di kawasan tersebut juga terdapat pusat perbelanjaan yang membuat jalur pedestrian selalu ramai oleh pejalan kaki. Meskipun fasilitas pejalan kaki sudah direnovasi oleh pemerintah kota Depok, tetapi

banyak dijumpai para pedagang kaki lima menggelar barang dagangangnya melebihi batas sampai ke tempat pejalan kaki. Sehingga hal tersebut dapat menghambat dan mengganggu aktivitas pejalan kaki di pedestrian. Untuk itu, perlu dilakukan studi tentang analisis karateristik dan tingkat pelayanan fasilitas pejalan kaki di Kawasan Terminal Angkutan Umum di Kota Depok.

Konsep Level Of Service (LOS) digunakan sebagai dasar standar untuk perencanaan ruang pejalan kaki. Konsep ini diklasifikasikan dalam enam standar tingkat pelayanan yaitu tingkat pelayanan $A$ sampai $F$, dimana akan menggambarkan tingkat kebebasan untuk memilih kecepatan berjalan, kemampuan untuk melewati pejalan kaki yang lain serta kemudahan dalam pergerakan persilangan dan berbalik arah pada berbagai pemusatan lalu lintas pejalan kaki. Dengan pertimbangan, kawasan Terminal Kendaraan Umum Kota Depok merupakan salah satu pusat kawasan di kota Depok yang selalu ramai dengan aktivitas pejalan kaki, maka perlu dilakukan penelitian mengenai karakteristik pejalan kaki di kawasan tersebut serta kapasitas dan tingkat pelayanannya apakah masih bisa menampung jumlah pejalan kaki yang ada.

\section{METODE}

Penelitian ini dilakukan di kawasan Terminal Kendaraan Umum, Kota Depok. Dalam penelitian ini dilakukan dengan penggal pengamatan sepanjang 5 meter pada kawasan yang ditinjau dan dipilih lokasi yang paling padat aktivitas para pejalan kaki. Penentuan lokasi penelitian diambil dari pengamatan pendahuluan (Observasi) yang dilakukan sebelum waktu pengumpulan data. Peta lokasi penelitian dapat dilihat pada Gambar 1.

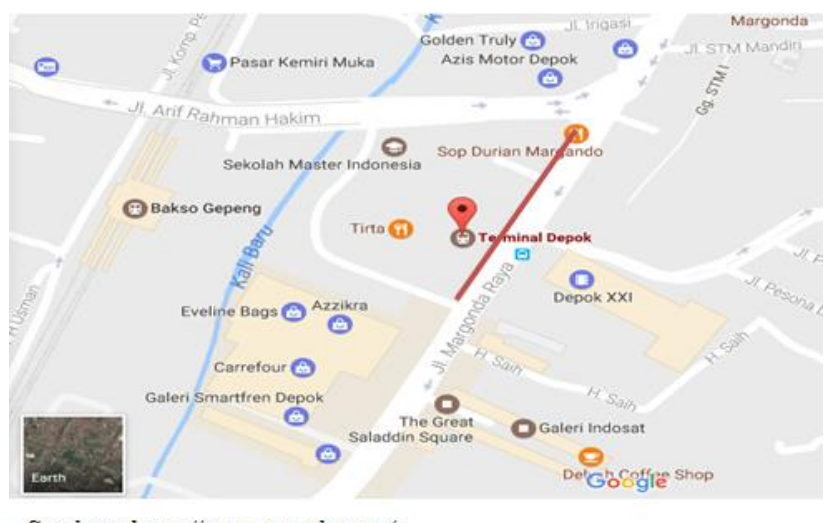

Sumber: https://maps.google.com/

Gambar 1. Peta Lokasi Penelitian

Dan penempatan surveyor pada masing-masing sisi jalur pejalan kaki dapat dilihat pada Gambar 2 


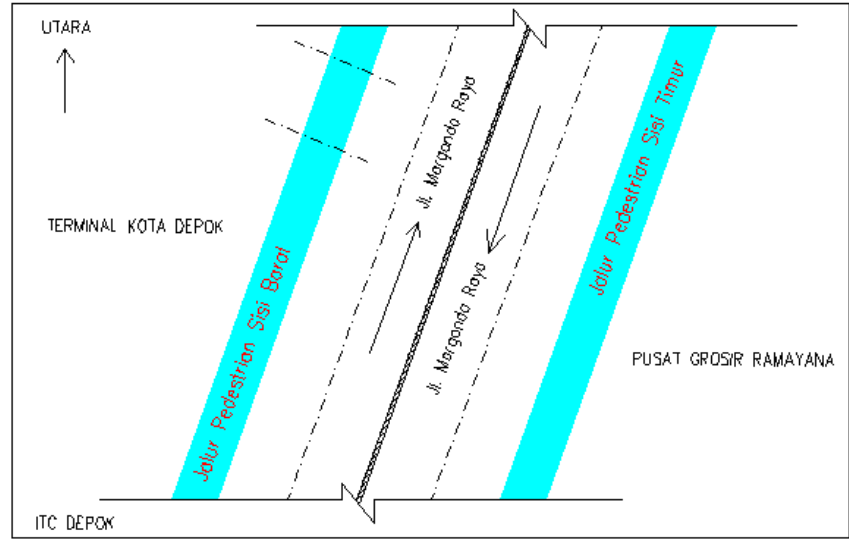

Gambar 2. Penempatan Surveyor

Keterangan :

$\begin{array}{lll} & \text { : Posisi Surveyor } \\ 1 & 1 & \text { : Batas Penggal Pengamatan } 5 \text { meter }\end{array}$

Dari gambar penempatan surveyor diatas, pada masingmasing garis acu ditempatkan satu kelompok surveyor. Kelompok surveyor yang berada di tepi garis acu AA menangani pedestrian yang bergerak dari arah Selatan ke Utara. Sedangkan kelompok surveyor yang berada di garis acu B-B menangani pedestrian yang bergerak dari arah Utara ke Selatan. Contoh penempatan surveyor pada salah satu sisi penggal pengamatan jalur pejalan kaki dapat dilihat pada Gambar 3

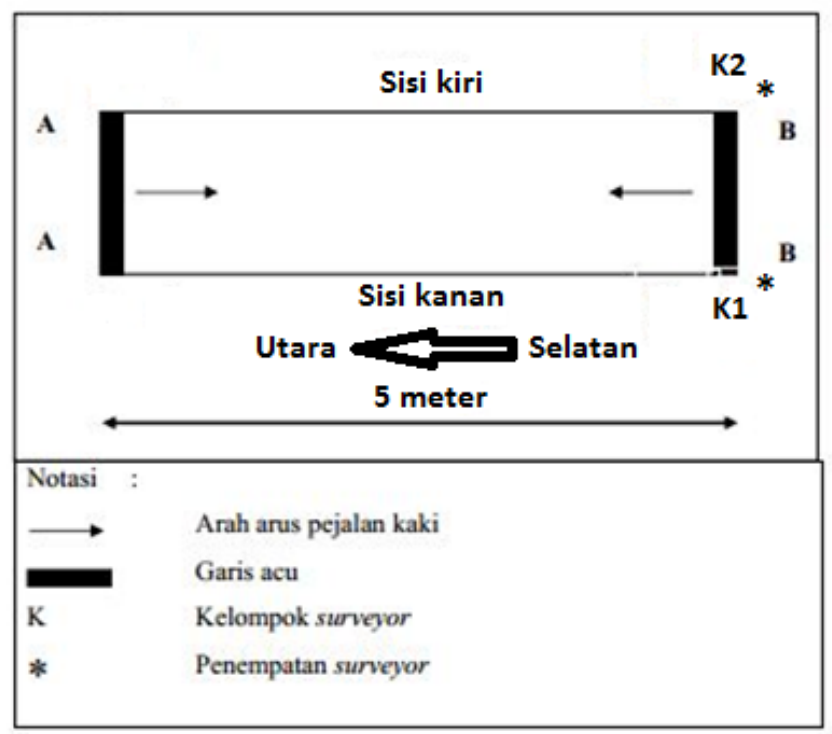

Gambar 3. Contoh Penempatan Surveyor

Agar tidak terjadi kesalahan pengumpulan data yang berganda, masing-masing kelompok surveyor menangani satu kelompok arus pejalan kaki saja seperti pada tabel 1

Tabel 1. Kelompok Surveyor

\begin{tabular}{|c|c|c|}
\hline $\begin{array}{c}\text { Garis } \\
\text { Acu }\end{array}$ & $\begin{array}{c}\text { Kelompok } \\
\text { Surveyor }\end{array}$ & $\begin{array}{c}\text { Arah Arus } \\
\text { Pedestrian }\end{array}$ \\
\hline A-A & K1 & S-U \\
\hline B-B & K2 & U-S \\
\hline
\end{tabular}

Setiap kelompok surveyor terdiri dari 2 orang yang mempunyai tugas masing- masing. Antara lain, yaitu :

1. Surveyor pertama, dengan alat ukur waktu, membaca waktu tempuh setiap pejalan kaki yang memasuki garis acu yang satu sampai ke garis acu berikutnya, dengan jarak 5 meter.

2. Sedangkan surveyor kedua, selain bertugas mencatat waktu tempuh pejalan kaki dari hasil pembacaan surveyor pertama, surveyor kedua ini juga dilengkapi alat ukur waktu untuk digunakan jika arus pejalan kaki sedang ramai.

Faktor manusia yang berpengaruh dalam proses pengambilan data lapangan seperti: penglihatan, perasaan lelah, dan sebagainya. Untuk mengurangi kesalahan akibat faktor manusia, disediakan kelompok surveyor yang mengganti surveyor yang merasa lelah.

Waktu penelitian di tentukan berdasarkan pengamatan pendahuluan (Observasi), yaitu survey sebelum pengambilan data jumlah arus pejalan kaki. Pengamatan pendahuluan (Observasi) ini dilakukan untuk mencari dan menganalisa waktu atau hari dengan jumlah pergerakan pejalan kaki yang paling padat. Cara survey pendahuluan untuk mendapatkan hari terpadat terhadap pergerakan pejalan kaki dilakukan dengan cara, antara lain :

1. Mengamati pergerakan pejalan kaki setiap hari pada jam yang sama.

2. Melakukan pengamatan secara visual, dan mendokumentasikan dengan foto ataupun video.

3. Dengan pengamatan pendahuluan untuk mencari hari dengan pergerakan pejalan kaki terpadat secara setiap hari pada jam yang sama, maka akan akan didapatkan analisa waktu atau hari yang cocok untuk melakukan penelitian karakteristik pejalan kaki pada hari yang paling padat.

Berdasarkan pengamatan pendahuluan yang dilakukan, maka di dapatkan waktu atau hari dengan analisa pergerakan yang paling padat yaitu pada hari jumat sore.

Instrumen yang digunakan pada penelitian ini untuk mengambil dan mengolah data antara lain :

1. Formulir untuk pengamatan jumlah pejalan kaki, serta untuk mencatat volume dan waktu tempuh pejalan kaki yang melewati penggal pengamatan 5 meter.

2. Formulir untuk menilai karakteristik fisik berdasarkan pengamatan secara visual.

3. Alat penghitung/Counter dan Stopwacth.

4. Meteran untuk mengukur batas penggal pengamatan 5 meter \& untuk mengukur lebar jalur pedestrian.

5. Alat tulis untuk mencatat.

6. Kamera video. 
Pengumpulan data di lapangan dilakukan hanya 1 kali di hari yang terpadat yaitu pada hari jumat sore pukul 16.00 - 17.50 WIB. Agar suatu penelitian dalam pelaksanaannya tidak dijumpai hambatan perlu adanya metode pengambilan data yang jelas. Dalam penelitian ini perhitungan kecepatan pejalan kaki dilakukan dengan urutan sebagai berikut :

1. Pada pedestrian di kawasan Terminal Kendaraan Umum Kota Depok dilakukan penandaan dua garis acu dengan jarak diukur menggunakan pita ukur / meteran sepanjang 5 meter.

2. Pada saat seseorang pejalan kaki melewati salah satu garis acuan, stop watch dihidupkan sampai melewati titik acuan berikutnya.

3. Untuk pengukuran kecepatan aliran bebas, data dianggap gagal bila pejalan kaki menghentikan aktivitasnya sebelum melewati titik acu berikutnya seperti memasuki dagangan para pedagang kaki lima.

4. Kecepatan pejalan kaki ditentukan dengan, membagi jarak antara dua titik acu (5 meter) dengan waktu tempuh oleh pejalan kaki yang dilaluinya dalam sekali lintasan dan dinyatakan dalam satuan meter per menit.

Variabel yang diukur dalam penelitian ini dikelompokkan menjadi dua bagian yaitu variabel untuk menentukan karateristik pejalan kaki dan tingkat pelayanan pejalan kaki. Berikut ini variabel-variabel yang disajikan dalam tabel 2 :

Tabel 2. Variabel Penelitian

\begin{tabular}{|c|c|}
\hline \multicolumn{2}{|c|}{$\begin{array}{l}\text { a. Variabel Untuk Menentukan Karateristik Pejalan } \\
\text { Kaki }\end{array}$} \\
\hline Variabel Penelitian & Indikator-indikator Penelitian \\
\hline Arus (flow) & $\begin{array}{l}\text { Jumlah pejalan kaki per menit per } \\
\text { lebar efektif trotoar }\end{array}$ \\
\hline Kecepatan (speed) & $\begin{array}{l}\text { kecepatan pejalan kaki pada } \\
\text { waktu penelitian }\end{array}$ \\
\hline $\begin{array}{l}\text { Kepadatan } \\
\text { (density) }\end{array}$ & Besarnya ruang pejalan kaki \\
\hline \multicolumn{2}{|c|}{$\begin{array}{l}\text { b. Variabel Untuk Menentukan Tingkat Pelayanan } \\
\text { Pejalan Kaki sesuai Pedoman Penilaian dari Australia }\end{array}$} \\
\hline Variabel Penelitian & Indikator-indikator Penelitian \\
\hline \multirow[t]{5}{*}{ Karateristik Fisik } & Akses \\
\hline & Lebar Jalur Pejalan Kaki \\
\hline & Kualitas Permukaan \\
\hline & Fasilitas Penyebrangan \\
\hline & Fasilitas Pendukung \\
\hline \multirow[t]{2}{*}{ Faktor Lokasi } & Jalan Penghubung \\
\hline & Lingkungan Jalur Pejalan Kaki \\
\hline \multirow[t]{3}{*}{ Faktor Pengguna } & Volume Pejalan Kaki \\
\hline & $\begin{array}{l}\text { Kombinasi } \text { Pengguna } \text { Fasilitas } \\
\text { Pejalan Kaki }\end{array}$ \\
\hline & Tingkat Keamanan \\
\hline
\end{tabular}

\section{Analisis Data : \\ Hubungan Antar Variabel Pergerakan Pejalan Kaki}

Prinsip analisis ini mendasarkan pada hubungan arus (flow), kecepatan (speed), dan kepadatan (density). Hubungan yang paling mendasar tersebut dapat dirumuskan seperti pada persamaan (1)

$\mathrm{Q}=\mathrm{Vs}$.

dengan, $\mathrm{Q}=$ arus (flow), (pejalan kaki $/ \mathrm{min} / \mathrm{m}$ )

$$
\begin{aligned}
& \mathrm{Vs}=\text { kecepatan rata- rata ruang, }(\mathrm{m} / \mathrm{min}) \\
& D=\text { kepadatan, }\left(\text { pejalan } \mathrm{kaki} / \mathrm{m}^{2}\right)
\end{aligned}
$$

\section{Model Greenberg}

Greenberg mengasumsikan bahwa hubungan matematis antara Kecepatan-Kepadatan bukan merupakan fungsi linear melainkan fungsi logaritmik (Ofyar Tamin, 2000). $\mathrm{D}=\mathrm{C} \cdot \mathrm{e}^{\mathrm{bVs}}$

Dimana $\mathrm{C}$ dan b bukan merupakan konstanta.

1). Hubungan antara kecepatan dan kepadatan

$$
\mathrm{Vs}=\frac{\operatorname{LnD}}{b}-\frac{\operatorname{LnC}}{b}
$$

2). Hubungan antara arus dan kepadatan

$$
\mathrm{Q}=\frac{D \operatorname{Ln} D}{b}-\frac{D \operatorname{LnC}}{b} \text {. }
$$

3). Hubungan antara arus dan kecepatan

$$
\mathrm{Q}=\text { Vs.C.e } \mathrm{e}^{\mathrm{b} . \mathrm{Vs}}
$$

Kondisi kepadatan maksimum (Dm) didapat dengan persamaan:

$\mathrm{Dm}=\mathrm{e}^{\mathrm{LnC}-1}$

Kondisi kecepatan pada saat arus maksimum (Vm) didapat dengan persamaan:

$\mathrm{Vm}=-\frac{1}{b}$

Kondisi pada saat arus maksimum $(\mathrm{Qm})$ didapat dengan persamaan:

$\mathrm{Qm}=\mathrm{Dm} \boldsymbol{x} \mathrm{Vm}$

\section{Tingkat Pelayanan}

Tingkat Pelayanan adalah penggolongan kualitas aliran traffic pada macam- macam fraksi kapasitas maksimum.

Kriteria yang digunakan sebagai syarat dalam menentukan tingkat pelayanan ada tiga acuan perbandingan yaitu:

1. Standar LOS menurut Peraturan Menteri Perkerjaan Umum Nomor : 03/PRT/M/2014

Dalam menentukan tingkat standar pelayanan pejalan kaki digunakan dari hasil perhitungan arus pejalan kaki maksimum dan kepadatan pejalan kaki maksimum. Standar LOS menurut Peraturan Menteri Perkerjaan Umum Nomor : 03/PRT/M/2014 dapat dilihat pada Tabel 3 
Tabel 3. Tingkatan Standar LOS Menurut Peraturan Menteri Perkerjaan Umum Nomor : 03/PRT/M/2014

\begin{tabular}{|c|c|c|c|c|}
\hline $\begin{array}{c}\text { Tingkat } \\
\text { Pelayanan }\end{array}$ & $\begin{array}{c}\text { Jalur } \\
\text { Pejalan } \\
\text { Kaki } \\
\left(\mathrm{m}^{2} / \text { orang }\right. \\
\text { ) }\end{array}$ & $\begin{array}{c}\text { Kecepatan } \\
\text { Rata-rata } \\
(\mathrm{m} / \mathrm{min})\end{array}$ & $\begin{array}{c}\text { Volume } \\
\text { Arus } \\
\text { (orang/ } \\
\mathrm{m} / \mathrm{min})\end{array}$ & $\begin{array}{c}\text { Volume / } \\
\text { Kapasitas } \\
\text { Rasio }\end{array}$ \\
\hline $\mathrm{A}$ & $\geq 12$ & $\geq 78$ & $\leq 6.7$ & $\leq 0.08$ \\
\hline $\mathrm{B}$ & $\geq 3.6$ & $\geq 75$ & $\leq 23$ & $\leq 0.28$ \\
\hline $\mathrm{C}$ & $\geq 2.2$ & $\geq 72$ & $\leq 33$ & $\leq 0.40$ \\
\hline $\mathrm{D}$ & $\geq 1.4$ & $\geq 68$ & $\leq 50$ & $\leq 0.60$ \\
\hline $\mathrm{E}$ & $\geq 0.5$ & $\geq 45$ & $\leq 83$ & $\leq 1.00$ \\
\hline $\mathrm{F}$ & $<0.5$ & $<45$ & Variabel & 1.00 \\
\hline
\end{tabular}

2. Penilaian Standar LOS dari Bangkok, Thailand

Dalam menentukan tingkat standar pelayanan pejalan kaki diperoleh dari perhitungan arus pedestrian maksimum dan kepadatan pejalan kaki maksimum. Standar LOS dari Bangkok, Thailand dapat dilihat pada Tabel 4

Tabel 4. Tingkatan Standar Pelayanan Fasilitas Pedestrian di Bangkok, Thailand

\begin{tabular}{|c|c|c|}
\hline LOS & Space $\left(\mathrm{m}^{2} /\right.$ ped $)$ & $\begin{array}{c}\text { Volume Arus } \\
(\text { ped } / \mathrm{m} / \mathrm{min})\end{array}$ \\
\hline A & $\geq 2.38$ & $\leq 28$ \\
\hline B & $1.6-2.38$ & $28-40$ \\
\hline C & $0.98-1.60$ & $40-61$ \\
\hline D & $0.66-0.98$ & $61-81$ \\
\hline E & $0.37-0.66$ & $81-101$ \\
\hline F & $\leq 0.37$ & 101 atau bervariasi \\
\hline
\end{tabular}

\section{Penilaian Standar LOS dari Australia}

Dalam menentukan standar penilaian tingkat pelayanan fasilitas pedestrian ini berdasarkan kondisi eksisting pada fasilitas pejalan kaki yang ada, kemudian dilakukan pengumpulan informasi dan penilaian terhadap faktor-faktor yang mempengaruhi tingkat pelayanan pejalan kaki yang nantinya akan menghasilkan rentang nilai untuk mengetahui tingkat pelayanan fasilitas pejalan kaki. Faktor-faktor yang mempengaruhi standar tingkat pelayanan fasilitas pejalan kaki dapat dilihat pada Tabel 5
Tabel 5. Faktor-faktor yang mempengaruhi standar tingkat pelayanan fasilitas pejalan kaki

\begin{tabular}{|c|c|c|c|}
\hline Kategori & Faktor LOS & Metode Penelitia & Contoh \\
\hline \multirow[t]{5}{*}{$\begin{array}{l}\text { Krakteristik } \\
\text { fisik }\end{array}$} & $\begin{array}{l}\text { Kesesuaian } \\
\text { Penggunaan }\end{array}$ & $\begin{array}{l}\text { Pemeriksaan } \\
\text { tempat }\end{array}$ & $\begin{array}{l}\text { Akses baik } \\
\text { untuk } \\
\text { difabel }\end{array}$ \\
\hline & $\begin{array}{l}\text { Lebar Jalur } \\
\text { Pejalan Kaki }\end{array}$ & $\begin{array}{l}\text { Mengukur Pada } \\
\text { saat survey }\end{array}$ & Lebar $>2 m$ \\
\hline & $\begin{array}{l}\text { Kualitas } \\
\text { Permukaan }\end{array}$ & $\begin{array}{l}\text { Memeriksa } \\
\text { pada saat } \\
\text { survey }\end{array}$ & $\begin{array}{l}\text { Kualitas } \\
\text { wajar,beberapa } \\
\text { retakan \& benjolan }\end{array}$ \\
\hline & $\begin{array}{l}\text { Fasilitas } \\
\text { Penyebrangan }\end{array}$ & $\begin{array}{l}\text { Memeriksa } \\
\text { pada saat } \\
\text { survey }\end{array}$ & $\begin{array}{l}\text { Fasilitas sai } \\
\text { memadai }\end{array}$ \\
\hline & $\begin{array}{l}\text { Fasilitas } \\
\text { Pendukung }\end{array}$ & $\begin{array}{l}\text { Memeriksa pada } \\
\text { saat survey }\end{array}$ & $\begin{array}{l}\text { Disediakan } \\
\text { cukup baik }\end{array}$ \\
\hline \multirow[t]{2}{*}{$\begin{array}{l}\text { Faktor } \\
\text { Lokasi }\end{array}$} & $\begin{array}{l}\text { Jalan } \\
\text { Penghubung }\end{array}$ & $\begin{array}{l}\text { Memeriksa pada } \\
\text { saat survey }\end{array}$ & $\begin{array}{l}\text { Ada dan } \\
\text { cukup baik }\end{array}$ \\
\hline & $\begin{array}{l}\text { Lingkungan } \\
\text { Jalur Pejalan Kaki }\end{array}$ & $\begin{array}{l}\text { Memeriksa pada } \\
\text { saat survey }\end{array}$ & $\begin{array}{l}\text { Dekat } \\
\text { dengan lalu } \\
\text { lintas kendaraan }\end{array}$ \\
\hline \multirow[t]{3}{*}{$\begin{array}{l}\text { Faktor } \\
\text { Pengguna }\end{array}$} & $\begin{array}{l}\text { Volume Pejalan } \\
\text { Kaki }\end{array}$ & $\begin{array}{l}\text { Perhitungan } \\
\text { jumlah pejalan } \\
\text { kaki selama } \\
\text { survey }\end{array}$ & $>350$ / hari \\
\hline & $\begin{array}{l}\text { Kombinasi } \\
\text { Pengguna } \\
\text { Jalur Pejalan Kaki }\end{array}$ & $\begin{array}{l}\text { Memeriksa } \\
\text { pada } \\
\text { saat survey }\end{array}$ & $\begin{array}{l}\text { Kurang } \\
\text { dari5\% pengguna } \\
\text { jalan di } \\
\text { atas roda }\end{array}$ \\
\hline & Tingkat Keamanan & $\begin{array}{l}\text { Menilai pada sa } \\
\text { survey }\end{array}$ & $\begin{array}{l}\text { Sangat } \\
\text { baik } \\
\text { dengan } \\
\text { adanya } \\
\text { pos polisi }\end{array}$ \\
\hline
\end{tabular}

Penilaian LOS menurut standar dari Australia menginformasikan bahwa standar tingkat pelayanan ini dapat digunakan untuk:

1. Untuk menggambarkan jaringan fasilitas pejalan kaki saat ini atau fasilitas pejalan kaki individu.

2. Sebagai alat analisis operasional untuk menkonfirmasi masalah yang ada

3. Untuk mengembangkan strategi guna meningkatkan jaringan pejalan kaki

4. Untuk mengukur kinerja dari strategi upaya pengembangan jaringan pejalan kaki

Dari pejelasan faktor-faktor yang mempengaruhi pada penilaian tingkat pelayan fasilitas pedestrian kemudian diketahui rentang nilai untuk menentukan tingkat pelayanan, seperti pada Tabel 6 . 
Tabel 6. Penilaian Untuk Alokasi Nilai LOS Pejalan Kaki Dari Australia.

\begin{tabular}{|c|l|c|}
\hline Tingkat LOS & \multicolumn{1}{|c|}{ Deskripsi } & Rentang Skor \\
\hline A & Ideal & $\geq 132$ \\
\hline B & Baik & $101-131$ \\
\hline C & Cukup & $69-100$ \\
\hline D & Buruk & $37-68$ \\
\hline E & Tidak Ideal & $\leq 36$ \\
\hline F & Adanya & $<15$ \\
\hline
\end{tabular}

\section{Pengembangan Kawasan Khusus Pejalan Kaki}

Penyediaan prasarana jaringan pejalan kaki berdasarkan (Permen PU No. 03 Tahun 2014) dilakukan melalui pengembangan kawasan khusus pejalan kaki harus memperhatikan ketentuan atau kriteria sebagai berikut:

1. lalu lintas dan sirkulasi kendaraan, di sekitar kawasan yang akan ditetapkan sebagai kawasan khusus pejalan kaki, memiliki arus lalu-lintas padat. Penerapan kawasan pejalan kaki seringkali akan menyebabkan arus lalu lintas lebih padat. Penerapan kawasan khusus pejalan kaki tidak diperkenankan mengurangi tingkat pelayanan jalan dengan perbandingan volume per kapasitas jalan $\leq 0.75$ atau minimal C. Oleh karena itu, penetapan salah satu jenis kawasan khusus pejalan kaki harus disertai pengaturan sirkulasi kendaraan dan tersedianya minimal 2 (dua) trayek angkutan umum (khusus sekitar full pedestrian mall).

2. pada tipe transit mall dan semi mall, pemberhentian angkutan umum dapat disediakan pada jalan tersebut. Namun dalam penerapan full mall, pemberhentian angkutan umum seperti bus, taksi atau kereta harus disediakan di luar jalan tersebut pada jarak maksimal 400 meter (jarak kemampuan orang berjalan kaki). Ruas jalan di sekitar full pedestrian mall harus dipersiapkan untuk memenuhi sarana-sarana pelengkap seperti tempat parkir, halte bus, tempat menaik-turunkan penumpang (drop-off) taksi dan zona bongkar muat.

3. sirkulasi pejalan kaki di sekitar kawasan yang akan ditetapkan sebagai kawasan khusus pejalan kaki, memiliki tingkat pelayanan trotoar melampaui $\mathrm{C}$ dan terdapat fasilitas penyeberangan dan terminal pejalan

\section{HASIL DAN PEMBAHASAN}

Setelah dilakukan analisis terhadap data-data yang diperoleh, maka karakteristik pergerakan pejalan kaki di Kawasan Terminal Kendaraan Umum Kota Depok dapat diketahui dari nilai arus, kecepatan, kepadatan yang terbesar hasil survei pada interval 5 menitan. Hasil perhitungan analisis dapat dilihat pada tabel 7 .

Tabel 7. Rekapitulasi Menurut Model Greenberg

\begin{tabular}{|l|c|}
\hline Hubungan & Sisi Barat \\
\hline Kecepatan- & $\mathbf{S = 3 5 , 2 8 0 - 5 , 5 1 8 ~ L n D ~}$ \\
Kepadatan & $\mathrm{R}=0,111$ \\
& $\mathrm{r}=-0,333$ \\
\hline Dm & 0,0010376 Pedestrian $/ \mathrm{m}^{2}$ \\
\hline Vm & $5,524 \mathrm{~m} / \mathrm{min}$ \\
\hline Qm & $0,00573 \mathrm{ped} / \mathrm{min} / \mathrm{m}$ \\
\hline
\end{tabular}

Kondisi hubungan antara variabel pergerakan pejalan kaki di Kawasan Terminal Kendaraan Umum Kota Depok yang dihitung dengan menggunakan Metode Greenberg:

- Ditinjau dari hasil hubungan antara kecepatan dan kepadatan sisi barat diperoleh nilai $r \quad(-0,333)$ yang menujukkan, apabila nilai kepadatan tinggi maka kecepatan akan makin berkurang karena ruang pejalan kaki semakin sempit demikian pula sebaliknya. Menurut Young (1982) koefisien korelasi (r) yang nilainya antara 0,20 s.d. 0,40 menunjukkan adanya hubungan yang rendah.

Dalam menentukan besarnya kapasitas pada jalur pejalan kaki di kawasan Terminal Kendaraan Umum Kota Depok dapat dinyatakan dengan besarnya arus (flow) maksimum jalur pejalan kaki yang di tinjau. Besarnya arus (flow) maksimum pejalan kaki di kawasan Terminal Kendaraan Umum Kota Depok berada pada pukul 17.45 -17.50 dengan arus maksimum 8,57 pedestrian $/ \mathrm{min} / \mathrm{m}$.

Untuk menghitung tingkat pelayanan pada fasilitas pejalan kaki di jalan tersebut, pada penelitian ini dihitung dengan tiga kategori, yang berdasarkan pada arus (flow) pejalan kaki pada interval 5 menitan yang terbesar, berdasarkan pada ruang (space) untuk pejalan kaki pada saat arus 5 menitan yang terbesar dan berdasarkan pengamatan dan penilaian di lokasi observasi yang merujuk pada standar Australia. Berikut ini rekapitulasi tingkat pelayanan pedestrian berdasarkan tiga acuan standar pada tabel 8 .

Tabel 8. Rekapitulasi Hasil Tingkat Pelayanan Pejalan Kaki

\begin{tabular}{|l|l|c|c|c|c|}
\hline \multicolumn{1}{|l|}{} & $\begin{array}{l}\text { Standar LOS dari } \\
\text { Leraturan } \\
\text { Menteri } \\
\text { Perkerjaan } \\
\text { Umum Nomor } \\
\text { 03/PRT/M/2014 }\end{array}$ & \multicolumn{2}{|l|}{$\begin{array}{l}\text { Standar LOS } \\
\text { Bangkok, } \\
\text { Thailand }\end{array}$} & $\begin{array}{l}\text { Standar } \\
\text { LOS } \\
\text { Australia, }\end{array}$ \\
\hline & Arus & Ruang & Arus & Ruang & \\
\hline $\begin{array}{l}\text { Sisi } \\
\text { Barat }\end{array}$ & $\mathrm{A}$ & $\mathrm{B}$ & $\mathrm{A}$ & $\mathrm{A}$ & $\mathrm{B}$ \\
\hline
\end{tabular}


Menurut John. J. Fruin, standar perencanaan fasilitas pejalan kaki di daerah perkotaan (urban) pada tingkat pelayanan $A$ dan $B$, hal ini berarti fasilitas pejalan kaki di jalan kaki di Kawasan Terminal Kendaraan Umum Kota Depok masih memenuhi standar perencanaan, dan masih mampu menampung jumlah pejalan kaki yang ada.

Diketahui bahwa tingkat pelayanan jalur pejalan kaki di kawasan Terminal Kendaraan Umum Kota Depok memiliki tingkat pelayanan seperti pada tabel 8 di atas. Dan fasilitas jalur pejalan kaki di kawasan Terminal Kendaraan Umum Kota Depok tidak memiliki tingkat pelayanan yang melampaui $\mathrm{C}$.

Dengan demikian fasilitas jalur pejalan kaki di kawasan Terminal Kendaraan Umum Kota Depok dapat dimanfaatkan atau dikembangkan hanya khusus untuk bagi para pejalan kaki atau pedestrian path. Sehingga tidak dapat dikembangkan menjadi pengembangan menjadi transit mall, semi mall, ataupun full mall.

\section{KESIMPULAN}

Dari penelitian ini dapat diterik kesimpulan sebagai berikut:

1. Karakteristik pergerakan pejalan kaki eksisting di kawasan Terminal Kendaraan Umum Kota Depok menunjukkan nilai arus memiliki nilai yang lebih kecil dibandingkan dengan nilai kapasitas/arus maksimum.

2. Hubungan antara variabel kecepatan dan variabel kepadatan dengan metode Greenberg dari pergerakan pejalan kaki di kawasan Terminal Kendaraan Umum Kota Depok, didapatkan harga $r=-0,333$ dan $R 2=0,111$. Menurut Young (1982) koefisien korelasi ( $r$ ) yang nilainya antara 0,20 s.d. 0,40 menunjukkan adanya hubungan yang rendah.

3. Kapasitas dan tingkat pelayanan fasilitas pejalan kaki di kawasan Terminal Kendaraan Umum Kota Depok adalah sebagai berikut:

a) Kapasitas arus maksimum yang bisa dilewatkan berdasarkan pada perhitungan pada jalur pejalan kaki kawasan Terminal Kendaraan Umum Kota Depok, memiliki kapasitas arus maksimum yang besar yaitu 8,571 pedestrian $/ \mathrm{min} / \mathrm{m}$.

b) Menurut penilaian berdasarkan standar tingkat pelayanan fasilitas pedestrian dari Peraturan Menteri Pekerjaan Umum No: 03/PRT/M/2014 diketahui bahwa tingkat pelayanan fasilitas pedestrian yang ada di Kawasan Terminal Kendaraan Umum Kota Depok berdasarkan nilai arus adalah "A" dan berdasarkan nilai ruang adalah "B". Sedangkan standar tingkat pelayanan dari Thailand, diketahui bahwa tingkat pelayanan fasilitas pedestrian yang ada di Kawasan Terminal Kendaraan Umum Kota Depok berdasarkan nilai arus dan nilai ruang mendapat tingkat pelayanan "A". Dan menurut standar tingkat pelayanan dari Australia yang menilai dari pengamatan visual di lapangan, diketahui bahwa tingkat pelayanan fasilitas pedestrian yang ada di Kawasan Terminal Kendaraan Umum Kota Depok adalah "B"

4. Tingkat pelayanan fasilitas pejalan kaki terendah di Kawasan Terminal Kendaraan Umum Kota Depok adalah "B". Berdasarkan data tingkat pelayanan fasilitas pejalan kaki yang didapatkan ini, maka disimpulkan pengembangan fasilitas pejalan kaki cukup di khususkan hanya untuk pejalan kaki / pedestrian path.

\section{UCAPAN TERIMA KASIH}

Terima kasih saya ucapkan kepada Ibu Dr. Ir. A.R. Indra Tjahjani, MT. yang telah membimbing, memberi arahan dan masukan dalam penelitian ini.

\section{REFERENSI}

Tanaboriboon, Yordphol dan Guyano, Jocelyn A. (1987). Level-of-Service Standarts for Pedestrian Facilities in Bangkok, Asian Institute of Technology, Bangkok, Thailand.

Government of Western Australia. (2006). Guidelines For Assessing Pedestrian Level Of Service, Western Australia.

Fruin, J.J. (1971). Pedestrian Planning and Design. Cruch Street Station, N.Y. : Metropolitan Association of Urban Designers and Environmental Planner.

RI (Republik Indonesia). (2014). Peraturan Menteri Pekerjaan Umum Nomor: 03/PRT/M/2014 Tentang Pedoman Perencanaan, Penyediaan, Dan Pemanfaatan Prasarana dan Sarana Jaringan Pejalan Kaki Di Kawasan Perkotaan.

Mannering ,Fred L.,\& Kilareski, Walter P. (1988). Principles of Highway Engineering and Traffic Analysis, Wiley, New York.

Papacostas, C.S. (1987) Transportation Engineering and Planning. University of Hawaii at Manoa Honolulu, Hawaii.

Puskarev, B.,\& M. Zupan, J. (1975). Urban Space for Pedestrian, The MIT Press, Cambridge, Massachusetts.

L. Huang .(2015). Dynamic Continuum Model for Bidirectional Pedestrian Flows. Journal of Engineering and Computational Mechanics. [online], 12 paragraphs. Tersedia di : http://www.google.com [2015, June 28]

Irawan, Benny. (2010). Analisis Karakteristik dan Tingkat Pelayanan Fasilitas Pejalan Kaki di Kawasan Pasar Gede Surakarta, Skripsi, Jurusan Teknik Sipil, Fakultas Teknik, Universitas Sebelas Maret. 
Wardhani, M. Ayu Kusuma. (2010). Studi Karateristik Pejalan Kaki Dengan Menggunakan Tiga Pendekatan (Studi Kasus Fasilitas Pejalan Kaki Galabo, Surakarta), Skripsi, Jurusan Teknik Sipil, Fakultas Teknik, Universitas Sebelas Maret.

Alam, Habib Kurnia (2017). Evaluasi Tingkat Pelayanan Jembatan Penyeberangan Orang (Studi Kasus Jembatan Penyeberangan Pasar Kartosuro Sukoharjo), Skripsi, Jurusan Teknik Sipil, Fakultas Teknik, Universitas Sebelas Maret. 
